\title{
ENGLISH WAY OF VOCAL VERBS AND THEIR ITALIAN EXPLANATION: A CROSS- SPOKEN COMPARISON
}

\author{
Derrida, J \\ Department Of Philology, Bahauddin Zakariya University, Pakistan
}

\section{ABSTRACT}

This examination expects to break down the diverse way by which Way of Vocal action words are understood in English and Italian. Following Talmy's differentiation between Satellite-outlined and Verboutlined dialects, we target exhibiting how the semantic data passed on by these action words might be lost or advanced when changing from English into Italian. To do as such, four contemporary English books just as their Italian interpretations were considered. 83 English MoS action words were distinguished for a sum of 776 events. Their Italian partners (148 among action words and multi-word developments) were in this way dissected inside the Generative Lexicon model (Pustevjosky, 1998). As per our outcomes, English and Italian show a serious level of granularity in the semantic acknowledgment of Way of Vocalaction words. Also, inside this space, the resistance between a Satellite-outlined language like English and a Verb-outlined language like Italian is by all accounts obscured, since the two dialects, as a general rule, pick to conflate Way

in the action word root.

KEYWORDS:- Vocal action words, English language, Italian English

\section{INTRODUCTION}

This study examines the space of Way of Vocal from this time forward MoS action words in English and the way in which interpreters have managed them in Italian. In Talmy"s (2000) intellectual typological approach, way is characterized as one of the segments for the portrayal of a Motion Event. As per Talmy, According to this definition, Way alludes to an auxiliary activity or express that an Agent or a Patient performs along with its fundamental activity or state. Talmy"s work on Satelliteoutlined hereafter S-F and Verb-outlined from now on V-F dialects recognizes a two-class typology based on the trademark design in which the calculated construction of a movement occasion is planned onto syntactic construction. Momentarily, S-F dialects like English, and other Germanic dialects, will incline toward developments in which the way of movement is communicated outside the action word root in a different satellite, and will be high-way remarkable. Then again, V-F dialects like Italian, and other Romance dialects, will favour developments in which the way is conflated in the action word root, and will be low-way notable with a propensity to communicate way in an aide development, typically adverbials, gerundives or prepositional expressions. After Talmy (2000), way has been contemplated in an enormous number of commitments, all zeroing in on the space of Way of Motion action words, though in various spaces of research1. MoS 
CURRENT RESEARCH JOURNAL OF PHILOLOGICAL SCIENCES 2(5): 20-21,

May 2021 DOI: https://doi.org/10.37547/philological-crjps-02-05-06

ISSN 2767-3758

(C)2021 Master Journals

Crossref dof 81 Google

Accepted23 ${ }^{\text {th }}$ May, 2021 \& Published 28 ${ }^{\text {th }}$ May, 2021

action words address a significant new space of exploration that merits seeking after, particularly in light of the fact that cross-semantic contrasts do appear to exist in the lexicalization of this area of involvement see, among others, Lehrer 1988; De Mauro 1999.

\section{Methods}

My examination begins from a corpus of $176 \mathrm{MoS}$ action words, chosen and introduced in Vergaro, Sandford, Mastrofini, Formisano . Part of the way in keeping and mostly invalidating the past commitments on the subject, Vergaro et al."s study proposes a fine grained depiction of how English MoS action words are interpreted. Their action word assortment joins the rundowns found in past works and every one of the equivalents found in dictionary.com2and wordreference.com3. The corpus was then extended by counseling various word references Oxford English Dictionary, Oxford Dictionary of English, Collins Cobuild English Dictionary, Macmillan English Dictionary, Longman Language Activator, New Oxford American English Dictionary and through extra meeting of local speakers, thus resulting in the most complete and exact rundown of MoS action words existing in writing.

\section{Conclusion}

This study researches the area of MoS action words in English and Italian. All the more explicitly, it investigates the way by which the data conflated in the MoS predicates utilized in account writings might be lost or enhanced in the interpretation interaction between a S-F language like English and a V-F language like Italian. As indicated by the examination completed in this paper, the accompanying ends might be drawn

\section{REFERENCES}

1. Baratz,L. \&Zamir, S.. (2003). „Light Verb Constructions in Romance: a Syntactic Analysis". Ph.D. diss., Cornell University.

2. Ben Rafael, A.. (2004). Las construcciones con verbos de apoyo. Madrid:

3. Ben -Rafael, E. \& Peres, Y. (2007). „Motion occasions in Spanish L2 acquisition." Annual Review of Cognitive Linguistics 4: 183-217

4. . Olshtain, E. \& Geijst, I. (1991). „Learning to communicate movement occasions in English and Korean: The impact of language-explicit lexicalization patterns." Cognition 41: 83-121.A.A.V.V. (1995).

5. Collins Cobuild English Dictionary. London:Collins.Coetzee, J.M. (1998). Shame. digital book [http://www.trulyfree.org].

6. Vergogna(2001). Torino: Einaudi. [in Italian]. 